\title{
О.А. Жеравина
}

\section{УНИВЕРСИТЕТСКИЕ ГОРОДА ИСПАНИИ КАК ОБЬЕКТЫ МИРОВОГО КУЛЬТУРНОГО НАСЛЕДИЯ}

\begin{abstract}
В статье рассматриваются Саламанка и Алькала-де-Энарес - старинные университетские города, входящие в список мирового культурного наследия, анализируются характерные особенности их университетов.

Ключевые слова: университетский город, Саламанка, Алькала-де-Энарес, испанские университеты, культурное наследие.
\end{abstract}

Испания занимает третье место по количеству объектов, включенных ЮНЕСКО в список мирового культурного наследия. Испания также относится к странам с наибольшим числом городов, находящихся в данном списке.

В числе пятнадцати испанских городов, имеющих статус исторических и являющихся частью мирового культурного наследия, есть два старинных университетских центра - Саламанка и Алькала-де-Энарес.

Испания принадлежит к числу европейских государств, обладающих богатым историко-культурным университетским наследием. Уже к Новому времени в стране существовало более 30 университетов, среди которых к наиболее престижным относились действующие и поныне Саламанкский университет, университеты Вальядолида, Алькала-де-Энарес (Алькала), Севильи, Гранады, Сантьяго-де-Компостела и ряд других.

Основанный в начале XIII в. в кастильской Саламанке университет входит в когорту старейших европейских университетов; он же представляет собой один из наиболее ярких символов испанской культуры. Университет Комплютенсе, появившийся три века спустя после Саламанкского в кастильском же городке Алькала-де-Энарес, стал воплощением грандиозного замысла кардинала Сиснероса, стремившегося осуществить в начале XVI в. масштабную реформу образования и воспитания испанского клира [1. Р. 11-13].

В целом каждый из старинных испанских университетов на протяжении веков становился неотъемлемой частью локальной, региональной и общенациональной культуры. Однако именно университеты Саламанки и Алькаладе-Энарес завоевали особое место в мировом университетском сообществе.

Саламанка на протяжении своей истории была центром обучения, снискавшим широкую известность в Испании и за ее пределами. Повседневная жизнь университетской корпорации определяла основные параметры бытия города; в его облике последовательно отражались этапы развития университета, роста его духовного и материального пространства. Университетские научные школы привлекали будущих юристов, медиков, теологов; открывающиеся коллегии академическую карьеру для неимущих студентов превращали в реальность. Реальностью становились и широкие возможности, которые открывались перед выпускниками Саламанкского университета на поприще государственной службы. 
Идеи величия знания, служения науке и монархии раскрывались не только в учебных аудиториях и в процессе научной деятельности, но и в самом архитектурном облике центра старинного города, в масштабах обустройства его университетских кварталов, барельефах, украшающих фасад главного здания университета и колоннаду центральной площади. В эпоху испанского Возрождения, ставшую временем наивысшего расцвета университета, Саламанка с ее дворцами, монастырями, жилыми домами, зданиями коллегий, улицами и дорогами стала зримым олицетворением университета.

Богатство историко-художественного наследия и состояние подлинно живого города как центра познания и науки позволило в 1988 г. утвердить Саламанку в качестве объекта мирового культурного наследия, а в 2002 г. культурной столицы Европы [2]. Из 6 критериев, по которым уникальные в своем роде объекты включаются в список всемирного наследия, Саламанка, по решению ЮНЕСКО, отвечает трем. Эти критерии указаны в описании данного объекта как «шедевра человеческого созидательного гения» (критерий I), свидетельствующего «о значительном взаимовлиянии человеческих ценностей... в определенном культурном пространстве...» (критерий II) и являющегося «выдающимся примером ... архитектурного ансамбля, который иллюстрирует значимый период человеческой истории» (критерий IV) [3].

В 1997 г. мэрией Алькала-де-Энарес, автономной коммуной Мадрида и университетом Алькала был подготовлен документ, в котором обосновывалась необходимость включения университета и исторического центра Алькала-де Энарес в список мирового культурного наследия. В заявке отмечалось, что в основе концепции города с его материальной, культурной, религиозной составляющими лежит разработанный кардиналом Сиснеросом проект по созданию университета. В отличие от распространенной практики возводить здание высшей школы в определенном городе, где впоследствии этот учебный центр обрастал необходимой инфраструктурой, Сиснерос придавал возводимому в Алькала университету фундаментальное значение, изначально планируя строительство всего необходимого для его функционирования. В результате город одновременно с появлением в нем университета обрел зримые материальные черты университетского центра, города, чей характер, согласно воплощенному плану Сиснероса, определялся логикой и особенностями функционирования университетской корпорации [4. С. 26-29]. Уникальность Алькала-де-Энарес, как подчеркивали авторы заявки, заключается в том, что он стал первой моделью университетского города эпохи раннего Нового времени.

Эту характеристику подтвердила делегация Международного совета по сохранению памятников и достопримечательных мест ИКОМОC (ICOMOS), которая посетила Алькала-де-Энарес в январе 1998 г. Специалистами совета было отмечено, что университет в Алькала не является старейшим ни в Европе, ни в Испании. Вместе с тем местом его рождения стал первый университетский город, построенный в качестве такового по заранее составленному плану, в котором основная застройка была подчинена нуждам процесса обучения и научных исследований. Отмечалось, что в этом Алькала отличается от старейших университетов Болоньи, Оксфорда, Кембриджа или Парижа, которые развивались в рамках существовавших и уже сформированных го- 
родских реалий, к которым этим университетам приходилось адаптироваться. Университет Алькала стал идеальной моделью для создаваемых испанскими миссионерами университетских центров в Южной Америке, а также для университетов Европы и других континентов [5].

По рекомендации ИКОМОС университет Алькала-де-Энарес и историческая часть города в 1998 г. были внесены в список объектов мирового культурного наследия [6]. Отметим, что наряду с критериями II и III, как в случае с Саламанкой, внесенной в этот список десятилетием ранее, город Алькала и его университет были выбраны также по критерию VI, сформулированному в отношении конкретного объекта следующим образом: «Вклад Алькала в интеллектуальное развитие человечества проявляется посредством материализации концепции Града Божьего, достижений в области лингвистики, которые имели здесь место, особенно в развитии испанского языка и благодаря тому, что Дон Кихот из Ла Манчи является шедевром Мигеля де Сервантеса Сааведры, самого выдающегося сына именно этого города» [5].

Включение в список объектов мирового культурного наследия университетских центров Испании, как и сравнительно большого числа других испанских городов, является не только делом чести и выражением международного признания. Это предполагает огромную ответственность со стороны государства, которое берет на себя обязательства по сохранению подобных объектов, расположенных на его территории. Сознавая сложность такого рода задач и масштабы необходимых экономических ресурсов, мэры городов Испании в 1993 г. создали ассоциацию городов мирового культурного наследия. Цель этой ассоциации - организация и осуществление совместных действий по сохранению исторического и культурного наследия этих городов, а также поддержание и укрепление того сложившегося образа жизни, который необходим этим историческим центрам. В практической деятельности и планах ассоциации участие в совместных проектах, согласование позиций; обмен опытом и объединение сил перед лицом общих трудностей.

16 января 2015 г. в ходе встречи Филиппа VI с мэрами 15 городов, входящих в ассоциацию, новому королю Испании были представлены результаты совместной деятельности по сохранению и популяризации испанских городов - объектов мирового культурного наследия [7].

Для университетских городов Испании наиболее актуальными остаются проблемы сохранения многопланового феномена университетской культуры, изучения этой культуры и передачи ее достижений последующим поколениям в качестве историко-культурного наследия. Понимание данной проблематики нашло свое воплощение в Саламанкской декларации об историкокультурном наследии университетов (2008) [8]. В этом документе ректоры ведущих испанских университетов подтвердили приверженность университетского сообщества принципу преемственности в восприятии и поддержке идей, содержащихся в международных соглашениях о культурном, историческом и художественном наследии человечества, подписанных европейскими странами на протяжении XX в.

Декларация была призвана привлечь внимание государства и общества к концепции испанского университета как неотъемлемой и весьма значимой части историко-культурного наследия страны. Подписавшие Саламанкскую 
декларацию ректоры обратились к европейскому сообществу с просьбой включить в европейский список историко-культурного наследия университетское наследие Испании [8. Р. 67-68].

Таким образом, была обозначена концепция университетского историко-культурного достояния Испании как совокупного феномена. Саламанка и Алькала как уже признанные объекты мирового культурного наследия составляют, пожалуй, самую яркую, но не единственную ипостась этого феномена, представляющего важную составляющую мирового культурного наследия.

\section{Литература}

1. Rodriguez-San Pedro Bezares L.E. Las Universidades Hispanas en la Edad Moderna. Un Balance // Las Universidades Hispanicas: de la Monarquia de los Austrias al Centralismo Liberal. Salamanca, 2000. P. 11-13.

2. Ciudades Patrimonio de la Humanidad: España. UNESCO. Salamanca [Электронный ресурс]. URL: http://www.ciudadespatrimonio.org/ciudades/index.php?cd=8 (дата обращения: 10.04.2015).

3. UNESCO. World Heritage List. Old City of Salamanca [Электронный pecypc]. ]URL: http://whc.unesco.org/en/list/381 (data obrascheniya: 12.04.2015).

4. Formulario para la inscripción en la lista del patrimonio mundial de la Universidad y recinto histórico de Alcalá de Henares. Primer modelo de ciudad universitaria de la edad moderna. Alcalá de Henares - Comunidad de Madrid - Universidad de Alcalá. 1997. 80 p. URL: https: //www.uah.es/patrimonio_humanidad/documentos/patrimoniohumanidad.pdf (data obrascheniya: 24.05.2015).

5. Alcalá de Henares patrimonio cultural de la humanidad // Vivat Academia, revista electrónica del «Grupo de Reflexión de la Universidad de Alcalá» (GRUA). - Marzo 1999. № 3 [Электронный ресурс]. URL: http://www3.uah.es/vivatacademia/anteriores/tres/patrimon.htm\#Acción del ICOMOS (data obrascheniya: 16.04.2015).

6. UNESCO. World Heritage List. University and Historic Precinct of Alcalá de Henares [Электронный ресурc]. URL: http://whc.unesco.org/en/list/876 (data obrascheniya: 12.04.2015).

7. Audiencia de SM el Rey a los alcaldes de las Ciudades Patrimonio de la Humanidad de España. 16 de enero del 2015. URL: http://www.ciudadespatrimonio.org/agenda/eventos.php?id=167 (data obrascheniya: 10.04.2015).

8. Declaración de Salamanca sobre el Patrimonio Histórico-Cultural de las universidades españolas // RdM. Revista de Museología: Publicación científica al servicio de la comunidad museológica. 2008. № 43. P. 66-68.

Zheravina Olga A. Tomsk State University (Tomsk, Russian Federation). E-mail: toledo@mail.tomsknet.ru. DOI 10.17223/22220836/18/5

UNIVERSITY CITIES OF SPAIN AS OBJECTS OF THE WORLD CULTURAL HERITAGE

Key words: University City, Salamanca, Alcala de Henares, Spanish universities, cultural heritage.

Spain takes the third place by amount of the objects included by UNESCO in the list of world cultural heritage. Among fifteen Spanish cities entering this list there are two ancient university centers Salamanca and Alcala de Henares. Spain has rich historical and cultural university heritage. By early Modern time in the country there were more than 30 universities among which there were Salamanca University, universities of Valladolid, Alcala de Henares (Alcala), Seville, Granada, Santiago de Compostela and others.

The university founded at the beginning of the XIII century in Castilian Salamanca is included into group of the oldest European universities and represents one of the brightest symbols of the Spanish culture. The university which appeared in Alcala de Henares three centuries later than that of Salamanca became realization of the plan of the cardinal Cisneros seeking to carry out a large-scale education reform of the Spanish clergy at the beginning of the XVI century. Many of ancient Spanish universities throughout centuries became an integral part of regional and national culture. However the universities of Salamanca and Alcala de Henares won a special place in world university community. 
Salamanca throughout the history was the center of study which got wide popularity in Spain and abroad. Stages of university development, growth of its spiritual and material space were consistently reflected in the image of the city. University schools of sciences involved future lawyers, physicians, theologians; the opening colleges turned the academic career for poor students into reality. During the era of the Spanish Renaissance which became time of the highest blossoming of the university Salamanca with its palaces, monasteries, houses, buildings of colleges, streets and roads became a visible embodiment of university. In 1988 Salamanca was approved as object of world cultural heritage.

In the application submitted in 1997 by Spain for inclusion of university and historic center of Alcala de Henares in the list of world cultural heritage it was noted that Cisneros's project on creation of university is the cornerstone of the concept of this University City. The city along with emergence of university in it found visible material lines of the university center, whose character, according to the realized plan of Cisneros, was defined by logic and features of functioning of University Corporation. Alcala became the first model of the university city of early modern times. According to the recommendation of ICOMOS the Alcala de Henares University and historical part of the city in 1998 were inscribed in the list of objects of world cultural heritage.

Salamanca and Alcala as already recognized objects of world cultural heritage make, perhaps, the brightest, but not the only form of this phenomenon representing an important component of world cultural heritage. 